\title{
The Development Of Mercury Ion Selective Electrode With Ionophore 7,16-Di-(2-Methylquinolyl)-1,4,10,13-Tetraoxa-7,16-Diazacyclooctad ecane (DQDC)
}

\author{
Eidi Sihombing ${ }^{1}$, Manihar Situmorang ${ }^{2}$, Timbangen Sembiring ${ }^{1} \&$ Nasruddin $^{1}$ \\ ${ }^{1}$ Department of Physics, Faculty of Mathematics and Natural Science, Universitas Sumatera Utara, Medan, \\ North Sumatra, Indonesia \\ ${ }^{2}$ Department of Chemistry, Faculty of Mathematics and Natural Science, Universitas Negeri Medan, Medan, \\ North Sumatra, Indonesia \\ Correspondence: Manihar Situmorang, Department of Chemistry, Faculty of Mathematics and Natural Science, \\ Universitas Negeri Medan, Medan, North Sumatra, Indonesia. Tel: 62-61-663-6757. E-mail: \\ msitumorang@lycos.com
}

Received: February4, 2015

Accepted: February17, 2015 Online Published: July 20, 2015

doi:10.5539/mas.v9n8p81

URL: http://dx.doi.org/10.5539/mas.v9n8p81

The research is financed by Research Project HibahBersaingUniversitasNegeri Medan (UNIMED), Directorate General of Higher Education (DGHE), Ministry of Research and Higher Education2015

\begin{abstract}
The development of mercury ion selective electrode (ISE-Hg) by using ionophore 7,16-Di-(2-methylquinolyl)-1,4,10,13-tetraoxa-7,16-diazacyclooctadecane (DQDC) in an electrode membrane sensing is explained. The study is aimed to construct an ion selective electrode for mercury by immobilization of ionophore DQDC in a polymeric PVC membrane electrode. Membrane electrode was constructed by casting and spin coated methods from the mixture of DQDC and plastisizer in a polymeric PVC matrix dissolved in a tetrahydofuran solvent. The membrane has been characterized and used as a sensing material in an ISE-Hg. The developed ISE-Hggive sensitive and selective response to mercury, working range linearity lies between 0.005 $\mathrm{mM}-1.0 \mathrm{mM} \mathrm{Hg}^{2+}$, slope $25.82 \mathrm{mV}$ per decade concentration of $\mathrm{Hg}^{2+}\left(\mathrm{r}^{2}=0.998\right)$.
\end{abstract}

Keywords: potentiometric; membrane electrode, ionophore, ion selective electrode, ISE-Hg, mercury

\section{Introduction}

The development of potentiometric method with using ion selective electrode (ISE) for mercury is a great challenge to obtain an alternative analytical tool for low cost, simple instrumentation, fast response, high selectivity, and wide linear detection system. Potentiometric method has been considered as an attractive detection method because of the cheap and simple instrumentation required, commonly a pH-meter (Situmorang, et al., 2008). Tungsten metal electrode due to its responsive to potential changes has been used as sensing device, and its compatible for sensing component has been demonstrated in the construction of potentiometric sensor (Situmorang, 2001). Tungsten electrode has also been used as transducer for potentiometric biosensors with immobilization of enzyme in polytyramine for malic acid (Situmorang, et al., 2001). It was demonstrated that electrodeposited polytyramine (Situmorang, et al., 1999) could act as a substrate electrode and retain its ability to determine potential change (Situmorang, et al., 2002).

Various analytical methods have been developed for determination of mercury, they are using spectrophotometric methods with adsorbing agent of 1,5-diphenylthiocarbazone (Khan, et al., 2005) or with o-carboxy phenyl diazoamino p-azobenzene (Chatterjeeetal, 2002). Spectrofluorometry with 2-hydroxy-1-naphthaldehydene-8-aminoquinolinefluorescent reagent has also introduced (Lietal, 2006). Chromatographic method has also been reported for the determination of mercury (Mondal\& Das, 2003; Hu, 2002). Amperometricmethod for the determination of mercury have been reported (Majid, et al., 2002; Lu, et al, 2003). Inductively coupled plasma mass spectrometry (ICP-MS) has also been introduced for mercury determination (Zhang, et al, 2004). Another method by using capillary electrophoresis (Páger\&Gáspár, 2002), 
and capillary electrophoresis inductively coupled plasma mass spectrometry with microconcentric nebulization has also been reported (Lee \& Jiang, 2000). The determination of mercury are still dominated by atomic absorption spectroscopy (AAS), those are withgraphite furnace atomic absorption spectrometry (Da-Silva, et al., 2002; Izgi, et al., 2000), electrothermal atomic absorption spectrometry (Moreno, et al., 2002), and cold vapor generation-electrothermal atomic absorption spectrometry (Moreda-Piñeiro, et al., 2002). In practice, cold vapor atomic absorption spectrophotometry (CV-AAS) is a good choice because it has superiority in accuracy and sensitivity (Silva, et al., 2006, Rizea, et al., 2007). However, those are with relatively high cost instruments.

Potentiometric determination of mercury by using diazacrownionophore membrane electrode has been reported (Yang, et al., 1997; Yang, et al., 1998). Potentiometric device with ISE by incorporation of ionophore in membrane electrode is a robust analytical method for the determination of mercury. It was believed the key aspects on the success for the construction of ISE is based on its design with the integration of ionophore onto the membrane electrode. The development of ISE-Hg reported in this study is based upon successfully in the construction of ISE by using ionophore sensing device for the determination of lead (Situmorang, 2005) and mercury (Purba, et al., 2013). The construction of PVC membrane electrodes with incorporating ionophore is very important in the development of ion selective electrode for mercury (ISE-Hg). The purpose of this paper is to develop a potentiometric sensor for mercury with incorporation of ionophore 7,16-Di-(2-methylquinolyl)-1,4,10,13-tetraoxa-7,16-diazacyclooctadecane (DQDC) that is immobilized in a polymeric PVC membrane electrode. Synthesis of sensing agents of ionophore DQDC, the strategy to incorporate ionophore on to the PVC membrane electrode, the construction of ISE-Hg, and the characterization of the electrode for its performance to mercury are demonstrated in this study. The application of the electrode to ion-sensing components for mercury ion in batch analysis is also described.

\section{Experimental}

\subsection{Reagents and Materials}

All chemicals are laboratory reagent grade and used as received except where indicated. Starting material of 1,4,10,13-tetraoxa-7,16-diazacyclooctadecane (DC), Poly(vinyl chloride) (PVC: low molecular weight type) as membrane matrix material, 2-nitrophenyl octyl ether (NPOE) as membrane plasticizer, potassium tetrakis (p-chlorophenyl) borate (KTpClPB) as anionic additive, 2-chloromethylquinoline, mercury nitrate, solvent of acetonitrile, tetrahydrofuran (THF), dichloromethane, and tungsten wire $(99.9 \%, \varnothing 0.5 \mathrm{~mm})$ were all purchased from Aldrich Chemical Company.

\subsection{Instrumentation}

Potentiometric measurements were made with a Keithley 177-Microvolt Digital Multi Meter (Keithley Instrument, USA) connecting with MacLab/8 Analog Digital Instrument, Sydney, Australia, for data acquisition. The ion selective electrodes assembled with a tungsten wire electrode was constructed followed the procedures explained in previous report (Purba, et al., 2014). Commercial $\mathrm{Ag} / \mathrm{AgCl}$ electrode containing $3 \mathrm{M} \mathrm{KCl}$ internal solution from Bioanalytical System (BAS) USA was used as reference electrode in all electrochemical experiments. High-resolutionscanning electron microscope, SEM (Zeiss Neon) is used for membrane morphology studies.

\subsection{Synthesis of Ionophore $D Q D C$}

Synthesis of ionophore as a sensing agent for mercury was very important part of the work because diazacrown ethers bearing a cation ligating pendant group on the nitrogen atom have successfully been used in cation membrane transport. Ionophore 7,16-Di-(2-methylquinolyl)-1,4,10,13-tetraoxa-7,16-diazacyclooctadecane is synthesized by the alkylation of 1,4,10,13-tetraoxa-7,16-diazacyclooctadecane with 2-chloromethylquinoline in acetonitrile containing sodium carbonate followed the modification of the procedures explained by Yang, et al., (1998). Another reaction was carried out in the dried analytical grade THF and dichloromethane solvents and done under an atmosphere of nitrogenas explained previously (Situmorang, et al., 2014).

\subsection{Preparation of Membrane Electrodes}

Preparation of membrane electrode is carried out by casting method and spin coated procedures to obtain sheet of PVC membrane from the mixture composition of matrix polymer PVC, plasticizer NPOE, ionophoreDQDC, with added the anionic additive for polymeric membraneKTpCIPB in THF solution. The casting method procedure to prepare membrane electrode containing of ionophore was conducted followed the procedures explained previously (Purba, et al., 2014; Purba, et al., 2013), it was the modification from the procedure explained by Yang, et al., (1998). The membrane composition (in weight \%) was 3\% ionophore DQDC, 30\% $\mathrm{PVC}, 67 \% \mathrm{NPOE}$ and $50 \mathrm{~mol} \% \mathrm{KTpClPB}$ were dissolved in $5 \mathrm{~mL}$ of dry tetrahydrofuran (THF) at constant 
stirring, and poured onto casting apparatus (petridis) followed by evaporation of the solvent to form a thin, flat, and clear membrane sheet. Spin coating procedure in the preparation of the electrode membrane was also carried out. The same quantity of the mixture of ionophore DQDC, PVC and plasticizer are dissolved in $5 \mathrm{~mL}$ THF as explained above, and the liquid was put on sputtering apparatus, followed by two steps spinning, at $600 \mathrm{rpm}$ for 10 second and at $800 \mathrm{rpm}$ for 30 second, then let the solvent to evaporate to form a thin, flat, and clear membrane sheet. The use of spin-coated techniques in the preparation of membrane electrode has advantage in the good reproducibility of membrane thickness, and the membrane sheet is compatibel for the construction of ion selective electrode.

\subsection{Preparation of ISE-Hg}

The strategy by using membrane type system is a considered choice to construct ISE-Hg due to the simple fabrication of the electrode. Preparation of ISE-Hg is carried out followed the procedures explained in previous study (Situmorang, et al., 2005) with modification to obtain a better sensing for mercury. The ISE-Hg with membrane electrode was fabricated by attaching a disc of $\varnothing 5 \mathrm{~mm}$ diameter PVC membrane, which is cut from the PVC membrane sheet prepared above, to PVC body (approximate $\varnothing 5.0 \mathrm{~mm}$ internal diameter and $60 \mathrm{~mm}$ length) at one edge is glued by using a light paste of PVC in THF solution. The electrode is then filled with internal solution of $10 \mathrm{mMHg}\left(\mathrm{NO}_{3}\right)_{2}$ and $10 \mathrm{mMKCl}$ solution. Pure tungsten (W) wire was firstly cleaned with $1 \mathrm{M}$ nitric acid for 1 minute, followed by sonication, and finally rinsed with distilled water. The $\mathrm{W}$-wire is then inserted into the electrode body that is immersed in an internal solution, and sealed the top with rubberseptum to construct an ISE-Hg. The $\mathrm{Ag} / \mathrm{AgCl}$ (BAS) was used for external reference electrode. The construction of PVC membrane liquid-contact electrodes is selected in the construction of electrode body design because the electrode assembly is simple in the incorporation of ionophore in to the electrode. The design of ISE-Hg is illustrated in Figure 1.


(c)

Figure 1. The design of ISE-Hg electrode containing of ionophore with PVC membrane liquid-contact electrode:

(a) membrane electrode containing of ionophore DQDC, (b) a PVC electrode body, and (c) the ISE-Hg

\subsection{Potentiometric Measurements}

An ISE-Hg and $\mathrm{Ag} / \mathrm{AgCl}$ reference electrode were immersed in a stirred bulk background solution of $10 \mathrm{~mL}$ nitric acid solution, $\mathrm{pH} 4.0$, containing $10 \mathrm{mM} \mathrm{KNO}_{3}$. Standard solution of $\mathrm{Hg}\left(\mathrm{NO}_{3}\right)$ at different concentration (accurately measured) was introduced to the electrochemical cell from a syringe followed by stirringafter each addition, successively starting from low concentration to higher concentrations of mercury standard solutions. Potential change was monitored on a digital $\mathrm{mV}$ meter interfaced with PowerLab, and the data were collected in personal computer. All measurements were carried out at $25 \pm 0.5{ }^{\circ} \mathrm{C}$. The calibration curve was done in the absence of interfering cations.

\section{Result and Discussion}

\subsection{Optimization of Membrane Composition}

Polymeric membrane of poly(vinyl chloride) (PVC) is popular to be used in the construction of ion selective electrode. The PVC is chosen as membrane matrix in this study with respect to the mechanical stability, chemical stability, chemical inertness (there is no competition with solution), the resulting membrane has no pores, and has low electrical resistance. The composition of ion-selective membranes have been optimized for mechanical properties to be suited for the construction of ISE-Hg. Membrane electrode at different ingredients consisted of 
matrix polymer PVC, plasticizer NPOE and KTpCIPB and ionophore DQDC has been fabricated by using casting and spin coated procedures. The mechanical properties of the membrane and the performance of the ISE-Hg electrodes prepared with these compositions are listed in Table 1.

Table 1. The composition of membrane ingredients, consisted of ionophore DQDC, matrix polymer PVC, and plasticizer NPOE, and anionic additive KTpClPB toward the membrane properties and electrode performances. The values given are to nearest weight percentage

\begin{tabular}{|c|c|c|c|c|c|c|c|c|}
\hline \multirow[t]{2}{*}{ No } & \multicolumn{4}{|c|}{ Composition in $5 \mathrm{~mL} \mathrm{THF}$} & \multicolumn{2}{|c|}{ Mechanical Properties of Membrane } & \multicolumn{2}{|c|}{ ISE-Hg Performance } \\
\hline & $\begin{array}{c}\text { PVC } \\
(\text { wt \%) }\end{array}$ & $\begin{array}{l}\text { NPOE } \\
(\text { wt \%) } \\
\end{array}$ & $\begin{array}{l}\text { DQDC } \\
(\mathrm{wt} \%) \\
\end{array}$ & $\begin{array}{c}\text { KTp-ClPB } \\
(\mathrm{mol} \%)\end{array}$ & Casting & Spin coating & Response & $\begin{array}{l}\text { Slope } \\
(\mathrm{mV})\end{array}$ \\
\hline 1 & 20 & 77 & 3 & 50 & $\begin{array}{l}\text { Clear, very elastic, } \\
\text { thin }\end{array}$ & $\begin{array}{l}\text { Clear, very elastic, } \\
\text { very thin }\end{array}$ & very fast & 25.42 \\
\hline 2 & 30 & 67 & 3 & 50 & Clear, very elastic & $\begin{array}{l}\text { Clear, very elastic, } \\
\text { thin }\end{array}$ & very fast & 25.26 \\
\hline 3 & 40 & 57 & 3 & 50 & Clear, elastic & Clear, elastic & Fast & 25.81 \\
\hline 4 & 50 & 47 & 3 & 50 & $\begin{array}{l}\text { Clear, elastic, } \\
\text { thick }\end{array}$ & Clear, elastic, thick & Slow & 22.11 \\
\hline 5 & 60 & 37 & 3 & 50 & White, rigid, thick & White, rigid, thick & Slow & 18.26 \\
\hline 6 & 70 & 27 & 3 & 50 & $\begin{array}{l}\text { White, rigid, very } \\
\text { thick }\end{array}$ & $\begin{array}{l}\text { White, rigid, very } \\
\text { thick }\end{array}$ & $\begin{array}{l}\text { Very } \\
\text { slow }\end{array}$ & 13.38 \\
\hline
\end{tabular}

The mechanical properties of membrane electrode are influenced by the composition of polymeric PVC and the plasticizer. It is observed that the thickness and hardness of the electrode membrane depended upon the amount of PVC used. When using higher amount of PVC the membrane became rigid, too dense, and resistive that results in longer response time needed in the potential measurement. However, a lower PVC content made the membrane too thin, results in poor mechanical strength, it is swelled up in the solution very fast, and broken easily. The membrane electrode prepared from low concentration of PVC (20 wt $\%)$ with high composition of plasticizer $(77 \mathrm{wt} \%)$ produce very thin membrane sheet with clear in color, where membrane texture is very elastic. This condition is adequat for the preparation of membrane electrode for ISE-Hg, but with short life time. Increasing the amount of PVC will increase the thickness of the membrane electrode but sacrifice in the elasticity of the membrane sheet. The membrane electrode prepared from high amount of PVC (70 wt $\%)$ with low concentration of plasticizer ( $27 \mathrm{wt} \%$ ) produce very thick membrane sheet with white in color, accompanied with rigid texture.The compositions of the membranes listed in Table 1 are compatible with the construction of ISE-Hg. The membrane prepared from very low amount of PVC (less than $20 \mathrm{wt} \%$ ) could not be used for electrode materials because it was swelling very fast in the solution and broken easily. Therefore, compromise in the composition of polymer and plasticizer has to be considered in the preparation of the electrode membrane to obtain the membrane with good mechanical properties for ISE-Hg. The membrane electrode made from $30 \%$ PVC and $67 \%$ plasticizer NPOE give good quality membrane. The membrane is then to be used to produce an ISE with good electrode performance based on its response sensitivity to mercury, and enhance the life time of the electrode for continuous uses.

The performance of ISE-Hg for mercury is influenced by the membrane composition in an electrode. Variation in the composition of polymer and plasticizer (PVC and NPOEa fixed amount of 3\% DQDC and $50 \mathrm{~mol} \%$ $\mathrm{KTpClPB}$ in the ingredient) on the electrode performanceis observed from the speed of sensing response to target analyte and the signal recovery to get constant baseline. The sensitivity of the electrode, it is based on the slope from the calibration curve of standard solution for the electrodes containing different ratios of plasticizer to PVC were summarized in Table 1. It is observed that the thickness of the membrane influenced the sensitivity of the electrode. The sensitivity of the electrode increased slightly with a decrease in the PVC content. The ISE-Hg made from the membrane electrode consisted of 30\% PVC and 67\% plasticizer NPOE is the most sensitive electrode for mercury. The higher the amount of plasticizer in the membrane improved the speed response of the electrode, but the mechanical properties of the electrode became much worse. The membrane was too soft, more permeable to water, easily swelling,internal solution is leaching, and results in a steady degradation of electrode performance.

The effect of the amount of KTpCIPB (anionic additive) on the ion-selectivity of the membrane was examined in the PVC membrane electrode. The presence of the anionic additive aided the efficiency of the electrodes towards 
the target cation by facilitating of the cation through the membrane. The addition of the anionic additive caused an increase in the response, a reduction of membrane resistance, an improvement of the speed of response, and a decrease in the effects of anions at high sample ionic strength. The best electrode response accompany with high selectivity was obtained when using $50 \mathrm{~mol} \% \mathrm{KTpCIPB}$ of the ionophore content of DQDC in the electrode membrane. Increase the amount of KTpClPB in the membrane formula caused an increase in the sensitivity, but the selectivity towards primary ion reduced, because the selectivity was strongly governed by the ion selective feature of the $\mathrm{KTpClPB}^{-}$anions. The membrane electrodes prepared with $30 \% \mathrm{PVC}, 67 \%$ plasticizer NPOE, 3\% $\mathrm{DQDC}$, and $50 \mathrm{~mol} \% \mathrm{KTpClPB}$ relative to the ionophore content provided good response to mercury. The membrane prepared at optimum condition has been observed by using SEM to obtain its surface at different amplification as shown in Figure 2. The SEM microscopy results showed that the contour of the membrane electrode containing ionophoreDQDC is not very smooth but it has no pore.

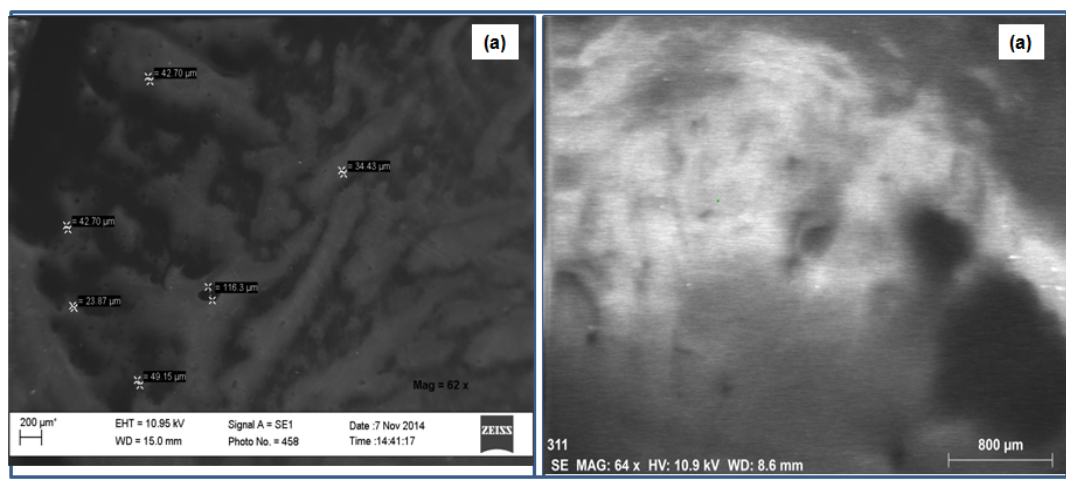

Figure 2. SEM images of PVC membrane electrode containing ionophore DQDCat different amplifications: (a) $200 \mu \mathrm{m}$, and (b) $800 \mu \mathrm{m}$

\subsection{Determination of $\mathrm{Hg}^{2+}$ by Using ISE-Hg Electrodes}

The electrode has been used for the determination of mercury in static system, and the potential was measured versus $\mathrm{Ag} / \mathrm{AgCl}$ in solution containing of $10 \mathrm{mM}$ potassium nitrate in nitric acid ( $\mathrm{pH} 4.0)$. Typical signal output for the determination of series concentrations of mercury standard solutions and their calibration curvesare presented in Figure 3. Potential responses given by the ISE-Hg electrode to mercury ion increaseswhen increasing the concentration of $\mathrm{Hg}^{2+}$ in the solution (Figure 3A). The ISE-Hg has good performance in nitric acid solution ( $\mathrm{pH} 4.0$ ) where the response signal gives positive values, and constant base line was achieved at 30 seconds after the addition of mercury. There was no drifting signal in this condition, and the electrode sensitivity shows nearly Nernstian response. The calibration profile of ISE-Hg for mercury standard solution is presented in Figure 3C. The electrode gave linear response for $0.005 \mathrm{mM}-1.0 \mathrm{mM} \mathrm{Hg}^{2+}$. A typical $95 \%$ confidence limit on the slope of ISE-Hg electrode is $25.82 \mathrm{mV}$ per decade concentration of $\mathrm{Hg}^{2+}$. The detection limit of an ISE-Hg electrode is $0.001 \mathrm{mM} \mathrm{Hg}^{2+}$, where signal to noise ratio is two $(\mathrm{S} / \mathrm{N}=2)$. For comparison purposes, an ion selective electrode in the absence of ionophore in the membrane electrode (ISE-without DQDC) is also prepared. The electrode is used to determine mercury the same procedures as for ISE-Hg, and the signal profile for an ISE is shown in Figure 3B. There was no signal observed for mercury when the concentration of $\mathrm{Hg}^{2+}$ increased in the solution. The results have proved that the electrode responses to mercury are mainly generated by the presence of ionophore DQDC in the membrane electrode. 

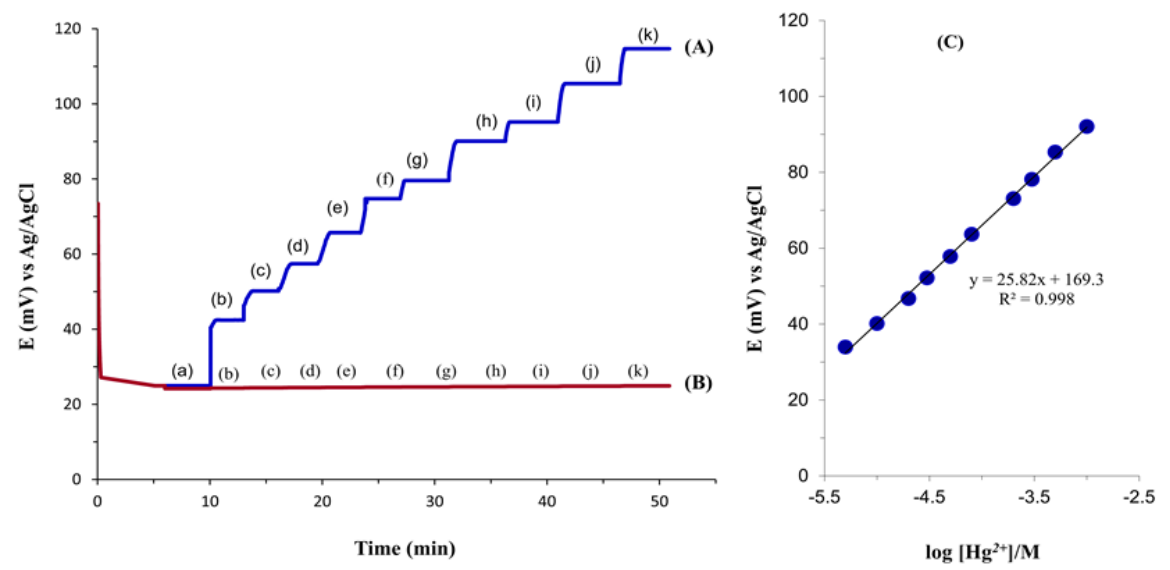

Figure 3. Typical response of ISE-Hg corresponding to successive addition of mercury in to nitric acid solution (pH 4.0) containing $10 \mathrm{mM} \mathrm{KNO}_{3}$ : (a) $0 \mu \mathrm{M}$, (b) $5 \mu \mathrm{M}$, (c) $10 \mu \mathrm{M}$, (d) $20 \mu \mathrm{M}$, (e) $30 \mu \mathrm{M}$, (f) $50 \mu \mathrm{M}$, (g) $0.1 \mathrm{mM}$, (h) $0.2 \mathrm{mM}$, (i) $0.3 \mathrm{mM}$, (j) $0.5 \mathrm{mM}$, and (k) $1.0 \mathrm{mM} \mathrm{Hg}^{2+}$. (A) ISE-Hg containingionophore DQDC, (B)

ISEwithout ionophore DQDC, (C) The calibration curve for mercury standard solution

\subsection{Effect of DQDC on Electrode Performance}

The effect of the quantity of ionophore in the membrane electrode was also investigated for electrode's sensitivity for mercury ion. The electrodes containing 1.5\%, 2\%, 3\% and 4\% DQDC respectively exhibited almost similar profileswith different in detection sensitivity (Figure 4). The electrode prepared with 3\% ionophore DQDC in the electrode membrane gave good performance to mercury ion and good sensitivity was achieved, the slope is $25.82 \mathrm{mV}$ per decade concentration of $\mathrm{Hg}^{2+}$. Response speed of the ISE-Hg at this condition is very fast, is only need 30 second to reach baseline for determination of mercury. An electrode constructed with $1.5 \%$ DQDC in the membrane electrode give low sensitivity (slope of $24.13 \mathrm{mV}$ ). The lifetime of the electrode with low concentration of ionophore was reduced due to slow leaching of entrapped DQDC from membrane when the electrode was washed during repeated uses. The electrode give good response to mercury when the amount of ionophore in the membrane electrode is $2 \%$ DQDC (slope of $25.26 \mathrm{mV}$ ). However, the response sensitivity is obtained lower than the sensitivity given by the ISE-Hg electrode containing 3\% DQDC in the membrane (slope is $25.82 \mathrm{mV}$ ). Furthermore, the crystals were observed in the electrode membrane when the content of ionophoreis increased to $4 \%$ DQDC. The electrode sensitivity at this condition was greatly reduced (slope of $22.74 \mathrm{mV}$ ). Therefore, the best condition on the preparation of ISE-Hg is chosen by immobilisation of ionophore 3\% DQDC in the membrane electrode.

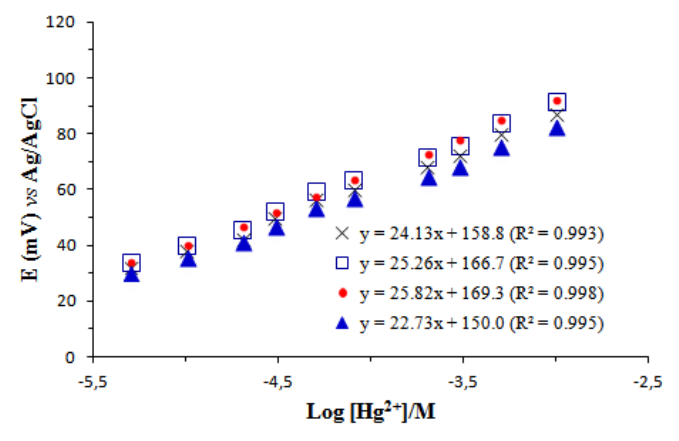

Figure 4. Calibration graphs for ISE-Hg for mercury when using different concentration of ionophore DQDC in electrode membrane: $(\times)$ ionophore $1.5 \%$, (口) ionophore $2.0 \mathrm{mg},(\bullet)$ ionophore $3.0 \mathrm{mg}$, and $(\mathbf{\Delta})$ ionophore $4.0 \%$

\subsection{Selectivity of ISE-Hg}

Selectivity of ISE-Hg has been tested for various types of cations, which are predicted to be interfering agents for mercury determination in real samples of polluted water samples. The response of ISE-Hg for $0.5 \mathrm{mM} \mathrm{Hg}^{2+}$ and the mixture of $0.5 \mathrm{mM} \mathrm{Hg}{ }^{2+}$ with $0.1 \mathrm{mMeach}$ of these cationsare listed Table 2. Those cations are 
successively $\mathrm{Mg}^{2+} ; \mathrm{Ca}^{2+} ; \mathrm{Zn}^{2+} ; \mathrm{Cu}^{2+} ; \mathrm{Cd}^{2+} ; \mathrm{Ni}^{2+} ; \mathrm{Al}^{3+} ; \mathrm{Fe}^{3+} ;$ and $\mathrm{Sn}^{3+}$. It was found that all cations added into mercury standard solution gave small change in the potential compare to a standard $0.5 \mathrm{mM} \mathrm{Hg}^{2+}$. Potential changes are vary between $1-5 \%$, where copper ion was the highest $(5 \%)$ response. However, at moderate concentration $(0.1 \mathrm{mM})$ of all those cations added into mercury standard solution were not interfere the measurement of the ISE-Hg. The results reveal that the developed ISE-Hg electrode is selective for mercury. The presence of ionophore DQDCin the membrane electrode has proven to give sensitive and selective response to mercury ion.

Table 2. The potential value of an ISE-Hg to $0.5 \mathrm{mM} \mathrm{Hg}^{2+}$ standard solution and the mixture of $0.5 \mathrm{mM}$ interfering cations and $0.5 \mathrm{mM} \mathrm{Hg}^{2+}$

\begin{tabular}{cccc}
\hline Mixture of Mercury and Interfering Cations & \multicolumn{3}{c}{ Electrode responses (E, mV) } \\
\cline { 2 - 4 } & Mean & Change in E* & \% Change* \\
\hline $\mathrm{Hg}^{2+}$ & 85.83 & - & - \\
$\mathrm{Mg}^{2+}$ & 87.93 & 2.10 & 2 \\
$\mathrm{Ca}^{2+}$ & 88.75 & 2.92 & 3 \\
$\mathrm{Zn}^{2+}$ & 87.60 & 1.77 & 2 \\
$\mathrm{Cu}^{2+}$ & 90.40 & 4.57 & 5 \\
$\mathrm{Cd}^{2+}$ & 88.44 & 2.61 & 3 \\
$\mathrm{Ni}^{2+}$ & 88.44 & 1.90 & 2 \\
$\mathrm{Al}^{3+}$ & 88.50 & 2.67 & 3 \\
$\mathrm{Fe}^{3+}$ & 87.97 & 2.14 & 2 \\
$\mathrm{Sn}^{3+}$ & 86.51 & 0.68 & 1 \\
\hline
\end{tabular}

*The electrode response for the mixture of $0.5 \mathrm{mM} \mathrm{Hg}^{2+}+0.5 \mathrm{mM}$ interfering agents is compared with $0.5 \mathrm{mM}$ $\mathrm{Hg}^{2+}$.

\subsection{Stability of ISE-Hg}

An ISE-Hg has been tested for its stability and the lifetime of the membrane electrode when the electrode is used to determine mercury at long period of time. Repeat determination of $0.5 \mathrm{mM} \mathrm{Hg}^{2+}$ (one measurement per day) was carried out for 30 days, and the relative resposess (\%) of the electrode is presented in Figure 5. The electrode exhibited good stability at normal uses for one month. The electrode signal is steady reduce to become $94 \%$ after 30 days. This results is promising where the PVC is compatible to be used as polymeric matrix in the immobilisastion of ionophore in the membrane electrode. The study is still now still under investigation to see if any response decreased due to the ionophore leaching out from the membrane for longer time of uses.

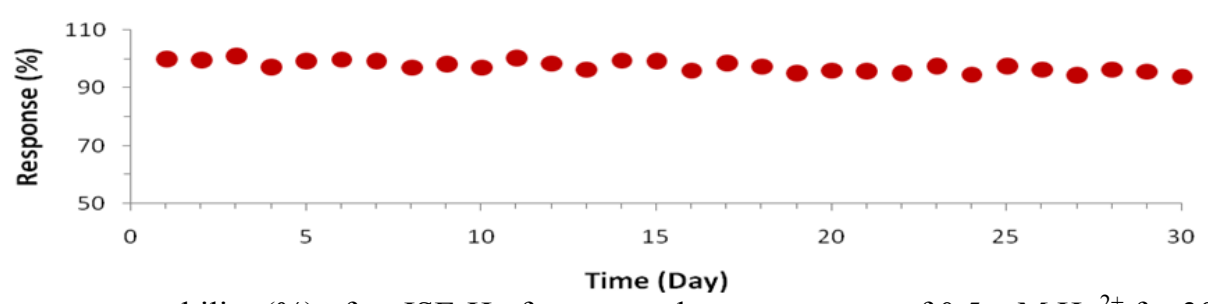

Figure 5. The response stability (\%) of an ISE-Hg for repeated measurements of $0.5 \mathrm{mM} \mathrm{Hg}^{2+}$ for 30 days

\section{Conclusion}

The preliminary work on the construction of ISE-Hg by using ionophore DQDC in a membrane electrode has successfully done. This work demonstrated the compatibility of polymeric PVC membrane electrodes with ionophore DQDC as sensing agent in an ion selective electrode. The ISE-Hg give sensitive response to mercury ion, the working linearity range lies between $0.005 \mathrm{mM}-1.0 \mathrm{mM} \mathrm{Hg}^{2+}$, slope $25.82 \mathrm{mV}$ per decade concentration of $\mathrm{Hg}^{2+}$, and the detection limit $0.001 \mathrm{mM} \mathrm{Hg}^{2+}$. This work is now still under investigation to obtain optimum conditions of the sensor for mercury.

\section{Acknowledgement}

The funding from Research Project Hibah Bersaing 2015 Universitas Negeri Medan (UNIMED), Directorate 
General of Higher Education (DGHE), Ministry of Research, Technology and Higher Education is acknowledged. Special thank is also expressed to Jamalum Purba, Melinda Lena Lamria, Henni Cintiya, and Kiki Agnesia Putri Br Sinulingga, staff of The Department of ChemistryUniversitas Negeri Medan, for their help to synthesis DQDC compound used in this study.

\section{References}

Chatterjee, S., Pillai, A., \& Gupta, V. K. (2002). Spectrophotometric determination of mercury in environmental sample and fungicides based on its complex with $o$-carboxy phenyl diazoamino $p$-azobenzene, Talanta, 57(3), 461 - 465. http://dx.doi.org/10.1016/S0039-9140(02)00037-1

da Silva, A. F., Welz, B., \& Curtius, A. J. (2002). Noble metals as permanent chemical modifiers for the determination of mercury in environmental reference materials using solid sampling graphite furnace atomic absorption spectrometry and calibration against aqueous standards, SpectrochimicaActa Part B: Atomic Spectroscopy, 57(12), 2031-2045. http://dx.doi.org/10.1016/S0584-8547(02)00175-1

de la Riva, B. S. V., Costa-Fernández, J. M., Jin, W. J., Pereiro, R., \& Sanz-Medel, A. (2002). Determination of trace levels of mercury in water samples based on room temperature phosphorescence energy transfer, AnalyticaChimicaActa, 455(2), 179-186. http://dx.doi.org/10.1016/S0003-2670(01)01597-5

de la Riva, B. S. V., Costa-Fernández, J. M., Pereiro, R., \& Sanz-Medel, A. (2000). Fluorimetric method for the determination of trace levels of mercury in sea water using 6-mercaptopurine. AnalyticaChimicaActa, 419(1), 33-40. http://dx.doi.org/10.1016/S0003-2670(00)00979-X

Hassan, S. S., Mahmoud, W. H., Mohamed, A. H., \&Kelany, A. E. (2006). Mercury(II) ion-selective polymeric membrane sensors for analysis of mercury in hazardous wastes. Anal Sci., 22(6), 877-881. http://dx.doi.org/10.2116/analsci.22.877

Hu, O., Yang, G., Yin, J., \& Yao, Y. (2002). Determination of trace lead, cadmium and mercury by on-line column enrichment followed by RP-HPLC as metal-tetra-(4-bromophenyl)-porphyrin chelates. Talanta, 57(4), 751-756.

Izgi, B., Demir, C., \& Güçer, S. (2000). Application of factorial design for mercury determination by trapping and graphite furnace atomic absorption spectrometry, SpectrochimicaActa Part B: Atomic Spectroscopy, 55(7), 969-975. http://dx.doi.org/10.1016/S0584-8547(00)00234-2

Khan, H., Ahmed, M. J., \& Bhanger, M. I. (2005). A simple spectrophotometric determination of trace level mercury using 1,5-diphenylthiocarbazone solubilized in micelle. Anal Sci., 21(5), 507-512. http://dx.doi.org/10.2116/analsci.21.507

Lee, T. H., \& Jiang, S. J. (2000). Determination of mercury compounds by capillary electrophoresis inductively coupled plasma mass spectrometry with microconcentric nebulization, AnalyticaChimicaActa, 413(1-2), 197-205. http://dx.doi.org/10.1016/S0003-2670(00)00807-2

Li, H., Zhang, Y., Zheng, C., Wu, L., Lv, Y., \& Hou, X. (2006). UV irradiation controlled cold vapor generation using $\mathrm{SnCl}_{2}$ as reductant for mercury speciation., Anal Sci., 22(10), 1361-1365. http://dx.doi.org/10.2116/analsci.22.1361

Li, J., He, F., \& Jiang, C. Q. (2006). Highly sensitive spectrofluorometric determination of trace amounts of mercury with a new fluorescent reagent, 2-hydroxy-1-naphthaldehydene-8-aminoquinoline. Anal Sci., 22(4), 607-611. http://dx.doi.org/10.2116/analsci.22.607

Lu, J., He, X., Zeng, X., Wan, O., \& Zhang, Z. (2003). Voltammetric determination of mercury (II) in aqueous media using glassy carbon electrodes modified with novel calix[4]arene. Talanta, 59(3), 553-560. http://dx.doi.org/10.1016/S0039-9140(02)00569-6

Majid, S., Rhazi, M. E., Amine, A., \& Christopher, M. A. (2002). An amperometric method for the determination of trace mercury(II) by formation of complexes with L-tyrosine. Analytica Chimica Acta, 464(1), 123-133. http://dx.doi.org/10.1016/S0003-2670(02)00422-1

Mondal, B. C., \& Das, A. K. (2003). Determination of mercury species with a resin functionalized with a 1,2-bis(o-aminophenylthio)ethane moiety. Analytica Chimica Acta, 477(1), 73-80. http://dx.doi.org/10.1016/S0003-2670(02)01372-7

Moreda-Piñeiro, J., López-Mahía, P., Muniategui-Lorenzo, S., Fernández-Fernández, E., \& Prada-Rodríguez, D. (2002). Direct mercury determination in aqueous slurries of environmental and biological samples by cold vapour generation-electrothermal atomic absorption spectrometry. Analytica Chimica Acta, 460(1), 111-122. 
http://dx.doi.org/10.1016/S0003-2670(02)00137-X

Moreno, R. G. M., de Oliveira, E., Pedrotti, J. J., \& Oliveira, P. V. (2002). An electrochemical flow-cell for permanent modification of graphite tube with palladium for mercury determination by electrothermal atomic absorption spectrometry. Spectrochimica Acta Part B: Atomic Spectroscopy, 57(4), 769-778. http://dx.doi.org/10.1016/S0584-8547(02)00009-5

Páger, Cs., \&Gáspár, A. (2002). Possibilities of determination of mercury compounds using capillary zone electrophoresis. Microchemical Journal, 73(1-2), 53-58. http://dx.doi.org/10.1016/S0026-265X(02)00050-4

Purba, J., Sibuea, G. V., Tarigan, M. L., Fonica, A., \& Situmorang, M. (2013). Sintesis Ionofor Sebagai Bahan Aktif Ion Selektif Elektroda (ISE) UntukAnalisis Penentuan Ion Logam Berat Di Dalam Sampel Lingkungan. Jurnal Penelitian Saintika, 13(2), 94-104.

Purba, J., Sinaga, M., \& Situmorang, M. (2012). Sintesis Ionofor Sebagai Bahan Aktif Ion Selektif Elektroda (ISE) Untuk Analisis Penentuan Ion Logam Berat, Prosiding Seminar dan Rapat Tahunan BKS PTN-B Bidang MIPA di Hotel Madani Medan,Tgl 11-12 Mei 2012, p. 181-185.

Purba, J., Tarigan, M. L., \& Situmorang, M. (2014). Pembuatan Elektroda Ion Selektif Merkuri Menggunakan Bahan Aktif Ionofor DTODC (Construction Of Ion Selective Electrode For Mercury By Using Ionofor DTODC, Prosiding Seminar dan Rapat Tahunan BKS PTN-B Bidang MIPA di Bogor, Tgl 9-11 Mei 2014.

Purba, J., Zainiati, \& Situmorang, M. (2013). Sintesis Ionofor Sebagai Bahan Aktif Ion Selektif Elektroda (ISE) Untuk Analisis Penentuan Logam Merkuri (Hg), Prosiding Seminar Hasil Penelitian Lembaga Penelitian Unimed Tahun 2013 Bidang Sain, Teknologi, Sosial, Bahasa dan Humaniora, Tgl 14-16 November 2013, 28-35.

Purba, J., Zainiati, Samosir, E. A., \&Situmorang, M. (2013). Pembuatan Ion Selektif Elektroda Menggunakan Ionofor DTODC Untuk Penentuan Merkuri (ISE-Hg), Prosiding Seminar dan Rapat Tahunan BKS PTN-B Bidang MIPA di Bandar Lampung, Tgl 10-12 Mei 2013, 207-211.

Rizea, M. C., Bratu, M. C., Danet, A. F., \& Bratu, A. (2007). Determination of mercury in fish tissue using a minianalyzer based on cold vapor atomic absorption spectrometry at the $184.9 \mathrm{~nm}$ line. Anal Sci., 23(9), 1121-1215. http://dx.doi.org/10.2116/analsci.23.1121

Silva, M. F., Tóth, I. V., \& Rangel, A. O. (2006). Determination of mercury in fish by cold vapor atomic absorption spectrophotometry using a multicommuted flow injection analysis system. Anal Sci., 22(6), 861-864. http://dx.doi.org/10.2116/analsci.22.861

Situmorang, M. (1992). Enzymatic Assay For Glucose And Cholesterol Using Flow Injection Potentiometry With A Tungsten Wire Electrode, M.Sc Thesis, The University of New South Wales, Australia.

Situmorang, M., (2005). Pembuatan Sensor Potensiometri Dalam Sistem Flow Injeksi Analisis Untuk Penentuan Timbal Menggunakan Ionofor Diazacrown. JurnalSain Indonesia, 29(2), 55-61.

Situmorang, M., Alexander, P. W., \& Hibbert, D.B., (1998). Flow injection potentiometry for enzymatic assay of cholesterol with a tungsten electrode 49,639-649.http://dx.doi.org/10.1016/S0039-9140(99)00057-0

Situmorang, M., Gooding, J. J., \& Hibbert, D. B. (1999). Immobilisation of Enzyme Throughout a Polytyramine Matrix: A Versatile Procedure for Fabricating Biosensors. Analytica Chimica Acta, 394(2-3), 211-223. http://dx.doi.org/10.1016/S0003-2670(99)00291-3

Situmorang, M., Gooding, J. J., Hibbert, D. B., \& Barnett, D. (2001). Development of Potentiometric Biosensors Using Electrodeposited Polytyramine as the Enzyme Immobilisation Matrix, Electroanalysis, 13(18), 1469-1474. http://dx.doi.org/10.1002/1521-4109(200112)13:18<1469::AID-ELAN1469>3.0.CO;2-U

Situmorang, M., Gooding, J. J., Hibbert, D. B., \& Barnett, D. (2002). The Development of a Pyruvate Biosensor Using Electrodeposited Polytyramine. 17-21.http://dx.doi.org/10.1002/1521-4109(200201)14:1<17::AID-ELAN17>3.0.CO;2-O

Situmorang, M., Purba, J., Lamria, M. L., Cintiya, H., Sinulingga, K. A. P., \& Sihombing, E. (2014). Sintesis Ionofor DTODC Sebagai Bahan Aktif Dalam Elektroda Ion Selektif Penentuan Merkury(ISE-Hg), JurnalPenelitianSaintika.

Situmorang, M., Simarmata, R., Napitupulu, S. K., Sitanggang, P., \& Sibarani, O. M. (2005). Pembuatan Elektroda Ion Selektif Untuk Penentuan Merkuri (ISE-Hg). Jurnal Sain Indonesia, 29(4), 126-134. 
Yang, X. H., Hibbert, D. B., \& Alexander, P. W. (1997). Continuous flow analysis of lead (II) and mercury (II) with substituted diazacrown ionophore membrane electrodes. Talanta, 45, 155-165. http://dx.doi.org/10.1016/S0039-9140(97)00122-7

Yang, X. H., Hibbert, D. B., \& Alexander, P. W. (1998). Flow Injection Potensiometry by PVC - Membrane Electrodes with Substituted AzacrownIonophore for the Determination of Lead (II) and Mercury (II) Ion. Analitica Chemica Acta, 372, 387-398. http://dx.doi.org/10.1016/S0003-2670(98)00382-1

Yantasee, W., Lin, Y, Hongsirikarn, K., Fryxell, G. E., Addleman, R., \& Timchalk, C. (2007). Electrochemical sensors for the detection of lead and other toxic heavy metals: The next generation of personal exposure biomonitors, Environ Health Perspect, 115(12), 1683-1690. http://dx.doi.org/10.1289/ehp.10190

Ye, G., Chai, Y., Yuan, R., \& Dai, J. (2006). A mercury(II) ion-selective electrode based on N,N-dimethylformamide-salicylacylhydrazone as a neutral carrier. Anal Sci., 22(4), 579-582. http://dx.doi.org/10.2116/analsci.22.579

Yoon, S., Albers, A. E., Wong, A. P., \& Chang, C. J. (2005). Screening mercury levels in fish with a selective fluorescent chemosensor. J Am Chem Soc., 127(46), 16030-16031. http://dx.doi.org/10.1021/ja0557987

Zhang, Z., Chen, S., Yu, H., Sun, M., \& Liu, W. (2004). Simultaneous determination of arsenic, selenium, and mercury by Ion exchange-vapor generation-inductively coupled plasma-mass spectrometry. Analytica Chimica Acta, 513(2), 417-423. http://dx.doi.org/10.1016/j.aca.2004.03.006

\section{Copyrights}

Copyright for this article is retained by the author(s), with first publication rights granted to the journal.

This is an open-access article distributed under the terms and conditions of the Creative Commons Attribution license (http://creativecommons.org/licenses/by/3.0/). 